\title{
Response to an oral fat load and effects on lipid profile, glycemia and high-sensitivity C-reactive protein after soybean extract consumption
}

\author{
Giuseppe Derosa, Angela D’Angelo, Davide Romano, Pamela Maffioli
}

Department of Internal Medicine and Therapeutics, University of Pavia, Pavia, Italy

Submitted: 17 June 2017

Accepted: 13 July 2017

Arch Med Sci 2018; 14, 4: 760-765

DOI: https://doi.org/10.5114/aoms.2017.70993

Copyright @ 2017 Termedia \& Banach

\section{Abstract}

Introduction: The aim of this study was to evaluate the response in terms of lipid profile, glycemia and high-sensitivity C-reactive protein after an oral fat load (OFL) with a non-dairy cheese cream containing fermented soybean extract soy, compared to a dairy cheese.

Material and methods: One hundred twenty-four healthy subjects underwent an OFL performed using a mixture containing non-dairy cheese cream, containing $75 \%$ fermented soybean extract (Valsoia Lo spalmabile), or a dairy cheese cream.

Results: During the OFL, total cholesterol and triglycerides at $6 \mathrm{~h}$ were lower with non-dairy cheese cream containing fermented soybean compared to dairy cheese cream. The value of low-density lipoprotein cholesterol recorded at $6 \mathrm{~h}$ with the active treatment was lower than the one recorded at the same time with the dairy cheese cream. A decrease of high-density lipoprotein cholesterol (HDL-C) was recorded with the dairy cheese cream, but not with the active treatment; moreover, the HDL-C value recorded with the active treatment was higher than the one observed with the dairy cheese cream. There was an increase of high-sensitivity C-reactive protein (hs-CRP) at 3,6 , and $9 \mathrm{~h}$ compared to $0 \mathrm{~h}$ with the dairy cheese cream, but not with the active treatment. The hs-CRP value observed with the active treatment was lower than the one observed with the dairy cheese cream.

Conclusions: A non-dairy cheese cream, containing $75 \%$ fermented soybean extract, caused a minor increase of lipid profile and of hs-CRP during OFL compared to a dairy cheese cream in healthy subjects.

Key words: cheese cream, lipid profile, non-dairy cheese cream, soybean extract.

\section{Introduction}

Post-prandial hypertriglyceridemia has been suggested to be a strong risk factor for cardiovascular disease, independent of the fasting plasma lipid level [1]. In the large Copenhagen City Heart Study cohort followed up for 26 years, the adjusted risk for myocardial infarction, ischemic heart disease, and all-cause mortality was nearly 1.5 for each $1 \mathrm{mmol} / \mathrm{l}$ increase in non-fasting triglyceridemia [2]. Normolipidemic patients affected by coronary artery disease appear to have a slower post-prandial lipid clearance than normolipidemic healthy subjects [3]. Moreover, post-prandial hyperlipidemia is linked to an acute endothelial dysfunc-

\author{
Corresponding author: \\ Prof. Giuseppe Derosa MD, \\ PhD \\ Department of Internal \\ Medicine and Therapeutics \\ University of Pavia \\ P. le C. Golgi, 19 \\ 27100 Pavia, Italy \\ Phone: +390382 526217 \\ Fax: +390382 526259 \\ E-mail: giuseppe.derosa@ \\ unipv.it
}


tion in moderately dyslipidemic patients, and the slower the post-load triglycerides (Tg) clearance is, the faster is the coronary atherosclerosis progression $[4,5]$. The oral fat load (OFL) is considered to be one of the more accurate models of post-prandial lipoprotein metabolism [6], and it has been widely used to evaluate the post-prandial fat load effect on single markers of inflammation [7], mainly in small samples of healthy subjects or in patients affected by metabolic diseases [8].

Derosa et al. have already studied the effect of an OFL on inflammation and endothelial stress markers and demonstrated that the OFL induces a complex systemic inflammatory response that includes interleukin-6 (IL-6), tumor necrosis factor- $\alpha$ (TNF- $\alpha$ ), high-sensitivity C-reactive protein (hs-CRP), and cell adhesion molecules, even before $\mathrm{Tg}$ levels significantly increase $[9,10]$.

In the literature, several nutraceuticals have been found to have positive action on lipid profile [1115]. Soy consumption has been associated with a modulation of lipid metabolism [16]. This positive effect was confirmed by the European Food Safety Authority (EFSA, Parma, ITALY) [17]. In epidemiological studies, the consumption of soy, soy isoflavones, or both, was inversely correlated with circulating levels of total cholesterol (TC) [18, 19], low-density lipoprotein-cholesterol (LDL-C) [19], and Tg [20], and positively correlated with the levels of high-density lipoprotein-cholesterol (HDL-C) [21].

For this reason, the aim of this study was to evaluate the response in terms of lipid profile, glycemia and hs-CRP after an OFL with a non-dairy cheese cream containing fermented soybean extract soy (Valsoia Lo spalmabile), compared to a dairy cheese in healthy subjects.

\section{Material and methods}

\section{Study design}

This double-blind, randomized, controlled, clinical trial was conducted at the Department of Internal Medicine and Therapeutics, University of Pavia and Fondazione IRCCS Policlinico San Matteo, Pavia (Italy). The study protocol was approved by the institutional review board and was conducted in accordance with the 1994 Declaration of Helsinki and its amendments and the Code of Good Clinical Practice [22]. All subjects provided written informed consent to participate in this study after a full explanation of the study had been given.

\section{Subjects}

We enrolled 124 Caucasian healthy subjects, aged $\geq 18$ years old, of either sex. Subjects with infective or inflammatory disorders were excluded, as well those taking anti-inflammatory medications. They were judged to be in good health on the basis of physical examination, medical history, routine blood work, urinalysis, and electrocardiogram. Subjects who smoked any amount of cigarettes during the previous 12 months were not included in the study. Subjects were eligible for inclusion if they had a condition of euglycemia (fasting plasma glucose $<100 \mathrm{mg} / \mathrm{dl}$ ), normotension according to the World Health Organization criteria (systolic blood pressure (SBP) $<140 \mathrm{~mm} \mathrm{Hg}$ and diastolic blood pressure (DBP) $<90 \mathrm{~mm} \mathrm{Hg}$ ) [23], a normal lipid profile (total cholesterol $<200$ $\mathrm{mg} / \mathrm{dl}$ and triglycerides $<150 \mathrm{mg} / \mathrm{dl}$ ) [24], and normal thyroid function. Women who were pregnant or breastfeeding or of childbearing potential and not taking adequate contraceptive precautions were also excluded. Apart from contraceptives pills, subjects were not taking any medication.

Suitable subjects, identified from a review of case notes and/or computerized clinic registers among blood donors attending the institute, were contacted by the investigators in person or by telephone.

\section{Oral fat load test}

The fat load was given between 8.00 and $9.00 \mathrm{~h}$ after a 12-h fast and a 3-day abstention from alcohol intake. Participants were also asked to refrain from intense exercise during the preceding days. The test drink consisted of a non-dairy cheese cream (Valsoia Lo spalmabile) or a dairy cheese cream. The fat meal was consumed within $10 \mathrm{~min}$. After the ingestion of the fat load, subjects were only allowed to drink water during the following $12 \mathrm{~h}$. Blood samples were drawn before and 3, 6, 9 , and $12 \mathrm{~h}$ after the fat load.

The composition of the non-dairy cheese cream and dairy cheese cream is shown in Tables I and II.

\section{Diet and exercise}

Subjects began a controlled-energy diet based on American Heart Association (AHA) recommendations [25] that included $50 \%$ of calories from carbohydrates, $30 \%$ from fat ( $6 \%$ saturated), and $20 \%$ from proteins, with a maximum cholesterol content of $300 \mathrm{mg} / \mathrm{day}$ and $35 \mathrm{~g} /$ day of fiber. Patients were not treated with vitamins or mineral preparations during the study.

\section{Assessments}

Before starting the study, all subjects underwent an initial screening assessment that included a medical history, physical examination, vital signs (blood pressure and heart rate), a 12-lead electrocardiogram, measurements of waist circumference (WC), abdominal circumference (AC), hip circumference $(\mathrm{HC})$, body mass index (BMI) calculated as body weight $(\mathrm{kg}) /$ height $(\mathrm{m})^{2}$, assessment of fasting plasma glucose (FPG), TC, LDL-C, HDL-C, Tg, 
Table I. Composition of non-dairy cheese cream (Valsoia Lo spalmabile) and dairy cheese cream

\begin{tabular}{|lc|}
\hline Non-dairy (soybean extract) cheese cream & Dairy cheese cream \\
\hline $\begin{array}{l}\text { Fermented soya extract 75\% } \\
\text { [water, soya beans (8.4\%), live cultures] }\end{array}$ & Pasteurized milk \\
\hline Coconut oil & Cream \\
\hline Dietary fiber & Salt \\
\hline Thickening agents: carrageenan-sodium alginate & Thickening agents \\
& (sodium alginate, flour of bean seeds, carrageenan) \\
\hline Stabilizer: pectin & \\
\hline Calcium phosphate, sea salt, vitamin $\mathrm{D}_{2}$ & \\
\hline
\end{tabular}

Table II. Nutritional composition of non-dairy cheese cream (Valsoia Lo spalmabile) and dairy cheese cream for $100 \mathrm{~g}$ of product

\begin{tabular}{|lcc|}
\hline Nutrients & Non-dairy (soybean extract) cheese cream & Dairy cheese cream \\
\hline Energy & $209 \mathrm{kcal}, 861 \mathrm{~kJ}$ & $280 \mathrm{kcal}, 1145 \mathrm{~kJ}$ \\
\hline Fats & $20 \mathrm{~g}(17 \mathrm{~g}$ saturated $)$ & $27.7 \mathrm{~g}(17.5 \mathrm{~g}$ saturated $)$ \\
\hline Carbohydrates & $1.8 \mathrm{~g}(1.3$ sugars $)$ & $2.7 \mathrm{~g}(2.6$ sugars $)$ \\
\hline Fibers & $3.3 \mathrm{~g}$ & $0.1 \mathrm{~g}$ \\
\hline Protein & $2.9 \mathrm{~g}$ & $4.5 \mathrm{~g}$ \\
\hline Salt & $0.5 \mathrm{~g}$ & $0.3 \mathrm{~g}$ \\
\hline Calcium & $120 \mathrm{mg}$ & - \\
\hline
\end{tabular}

lipoprotein (a) [Lp(a)], apolipoprotein A-I (Apo A-I), apolipoprotein B (Apo B), and Hs-CRP. All variables were assessed at baseline and during OFL.

For a description of how various parameters were assessed, please see our previous paper [26].

\section{Statistical analysis}

Distribution of all variables was tested with the Kolmogorov-Smirnov normality test. Baseline and post-OFL values of normally distributed parameters were compared using repeated measures analysis of variance (ANOVA). Baseline and postOFL values of non-normally distributed parameters were compared by applying non-parametric analysis of variance (Kruskal-Wallis). Differences over time and the association with the parameters were evaluated with stepwise multiple linear regression analysis. Outcome variables with a skewed distribution were transformed to a log scale before statistical testing [27]. A $p$-value of less than 0.05 was considered statistically significant. All tests were two-sided. Statistica 6.0 (StatSoft, Inc. 2003, Tulsa, OK, US) was used for statistical computations. All results are expressed as mean \pm standard deviation (SD).

\section{Results}

\section{Studied sample}

A total of 124 subjects were enrolled in the trial. $49.2 \%$ of them (61) were randomized to the active treatment (cheese cream, containing fermented soybean), and $50.8 \%$ (63) to a dairy cheese cream. Subjects' data of both groups are listed in Table III.

\section{Oral fat load}

Both TC and Tg levels increased at 3, 6 and $9 \mathrm{~h}$ after OFL in the active treatment ( $p<0.05$ for all) or dairy cheese arms $(p<0.05, p<0.01, p<0.05$ respectively) (Figure 1 ). TC and Tg levels recorded with active treatment after $6 \mathrm{~h}$ were lower compared to the ones recorded at the same time with the dairy cheese cream $(p<0.05)$.

Regarding LDL-C, there was an increase at 3 $(p<0.05), 6$ ( $p<0.01)$, and $9 \mathrm{~h}(p<0.05)$ compared to $0 \mathrm{~h}$ during the OFL performed with the dairy cheese cream, and at $6 \mathrm{~h}$ with the active treatment $(p<0.05)$; moreover, the LDL-C value recorded at $6 \mathrm{~h}$ with the active treatment was lower than the one recorded at the same time with the dairy cheese cream $(p<0.05)$ (Figure 1$)$.

A decrease of HDL-C was recorded at 6 and $9 \mathrm{~h}$ compared to $0 \mathrm{~h}$ with the dairy cheese cream ( $p<0.05$ for both). No changes were recorded with the active treatment. The HDL-C value recorded with the active treatment was higher than the one recorded with the dairy cheese cream at 6 and $9 \mathrm{~h}$ ( $p<0.05$ for both) (Figure 1).

Regarding hs-CRP, there was an increase at 3 $(p<0.05), 6(p<0.01)$, and $9 \mathrm{~h}(p<0.05)$ compared to $0 \mathrm{~h}$ with the dairy cheese cream, while no dif- 
Table III. Subjects' data in non-dairy (soybean extract) cheese cream and dairy cheese cream treatment groups at baseline

\begin{tabular}{|lccc|}
\hline Parameter & Dairy cheese cream & $\begin{array}{c}\text { Non-dairy (soybean extract) } \\
\text { cheese cream }\end{array}$ & P-value \\
\hline$N$ & 61 & 63 & - \\
\hline Sex $(\mathrm{M} / \mathrm{F})$ & $31 / 30$ & $32 / 31$ & 0.146 \\
\hline Age $[$ years] & $53.4 \pm 9.4$ & $54.2 \pm 10.2$ & 0.196 \\
\hline Women taking contraceptives & 5 & 7 & 0.223 \\
\hline Height $[\mathrm{m}]$ & $1.66 \pm 0.04$ & $1.67 \pm 0.05$ & 0.210 \\
\hline Weight $[\mathrm{kg}]$ & $72.4 \pm 8.2$ & $75.5 \pm 9.4$ & 0.187 \\
\hline BMI $\left[\mathrm{kg} / \mathrm{m}^{2}\right]$ & $26.2 \pm 2.0$ & $26.3 \pm 2.1$ & 0.247 \\
\hline WC $[\mathrm{cm}]$ & $90.8 \pm 6.9$ & $90.1 \pm 6.7$ & 0.221 \\
\hline HC $[\mathrm{cm}]$ & $102.4 \pm 8.8$ & $103.5 \pm 9.4$ & 0.091 \\
\hline AC $[\mathrm{cm}]$ & $93.1 \pm 6.8$ & $93.8 \pm 7.2$ & 0.128 \\
\hline FPG $[\mathrm{mg} / \mathrm{dl}]$ & $90.3 \pm 7.7$ & $89.8 \pm 7.1$ & 0.096 \\
\hline TC $[\mathrm{mg} / \mathrm{dl}]$ & $183.6 \pm 14.2$ & $181.9 \pm 13.2$ & 0.082 \\
\hline LDL-C $[\mathrm{mg} / \mathrm{dl}]$ & $110.6 \pm 9.3$ & $110.2 \pm 8.9$ & 0.088 \\
\hline HDL-C [mg/dl] & $48.1 \pm 6.1$ & $47.5 \pm 5.7$ & 0.073 \\
\hline Tg $[\mathrm{mg} / \mathrm{dll}]$ & $124.7 \pm 32.8$ & $122.1 \pm 31.5$ & 0.081 \\
\hline Lp $(\mathrm{a})[\mathrm{mg} / \mathrm{dll}]$ & $14.6 \pm 12.4$ & $15.8 \pm 13.2$ & 0.069 \\
\hline Apo A-l $[\mathrm{mg} / \mathrm{dll}]$ & $127.3 \pm 20.8$ & $125.1 \pm 18.9$ & 0.072 \\
\hline Apo B $[\mathrm{mg} / \mathrm{dl}]$ & $114.6 \pm 16.5$ & $113.9 \pm 16.1$ & 0.070 \\
\hline Hs-CRP $[\mathrm{mg} / \mathrm{l}]$ & $0.9 \pm 0.6$ & $0.8 \pm 0.5$ & 0.077 \\
\hline
\end{tabular}

Data are means $\pm S D$. BMI - body mass index, WC - waist circumference, HC - hip circumference, AC - abdominal circumference, FPG fasting plasma glucose, TC - total cholesterol, LDL-C - low-density lipoprotein cholesterol, HDL-C - high-density lipoprotein cholesterol, $\mathrm{Tg}$-triglycerides, Lp(a) - lipoprotein (a), Apo A-I-apolipoprotein A-I, Apo B-apolipoprotein B, hs-CRP-high-sensitivity C-reactive protein.

ferences were recorded during the OFL performed with the active treatment. The hs-CRP value observed with the active treatment was lower than the one observed with the dairy cheese cream at $6 \mathrm{~h}$ ( $p<0.05$ for both) (Figure 1).

\section{Discussion}

Our study showed that OFL performed with a non-dairy cheese cream containing fermented soybean extract soy gave a minor increase of TC, $\mathrm{Tg}$, and LDL-C and a minor decrease of HDL-C compared to a dairy cheese in healthy subjects. Our results are in agreement with those already observed by Shige et al. [28] in Japanese people; these authors evaluated the effects of soybean protein and casein on post-prandial lipemia using OFL. They reported that 3 weeks of $20 \mathrm{~g} /$ day of soy protein isolate dietary supplement favorably affected the post-prandial remnant lipoprotein response as compared to the casein dietary supplement. In the literature soybean protein is reported to selectively inhibit the absorption of cholesterol in experimental animals, while it does not affect the absorption of $\mathrm{Tg}$ [29]. Soybean protein, compared to casein, raises hepatic LDL receptor activity [30-33], alters insulin level [34] and raises lipopro- tein lipase activity [35]. It has previously been observed that post-prandial triglyceridemia is associated with several factors involved in inflammation and endothelial dysfunction, such as interleukin-6 (IL-6), tumor necrosis factor- $\alpha$ (TNF- $\alpha$ ), hs-CRP, and cell adhesion molecules, that increase during OFL $[9,10]$. Similarly to our previous studies, we recorded an increase of hs-CRP during OFL; however, hs-CRP was lower with the non-dairy cheese cream compared to the dairy cheese cream. Taking into account that post-prandial lipoproteins can activate leukocytes in the blood and up-regulate the expression of leukocyte adhesion molecules on the endothelium [36], facilitating adhesion and migration of inflammatory cells into the subendothelial space, probably the minor increase of lipid profile during OFL corresponds to minor endothelial damage, with a minor increase of hs-CRP.

We believe that the positive action of soybean observed in this study could be clinically significant; in particular, soybean could be an ally in clinical practice to help patients to control their lipid profile in addition to a healthy lifestyle. Of course, our study has some limitation: the most important is the inequality concerning the contents of the tested products; the small sample enrolled 

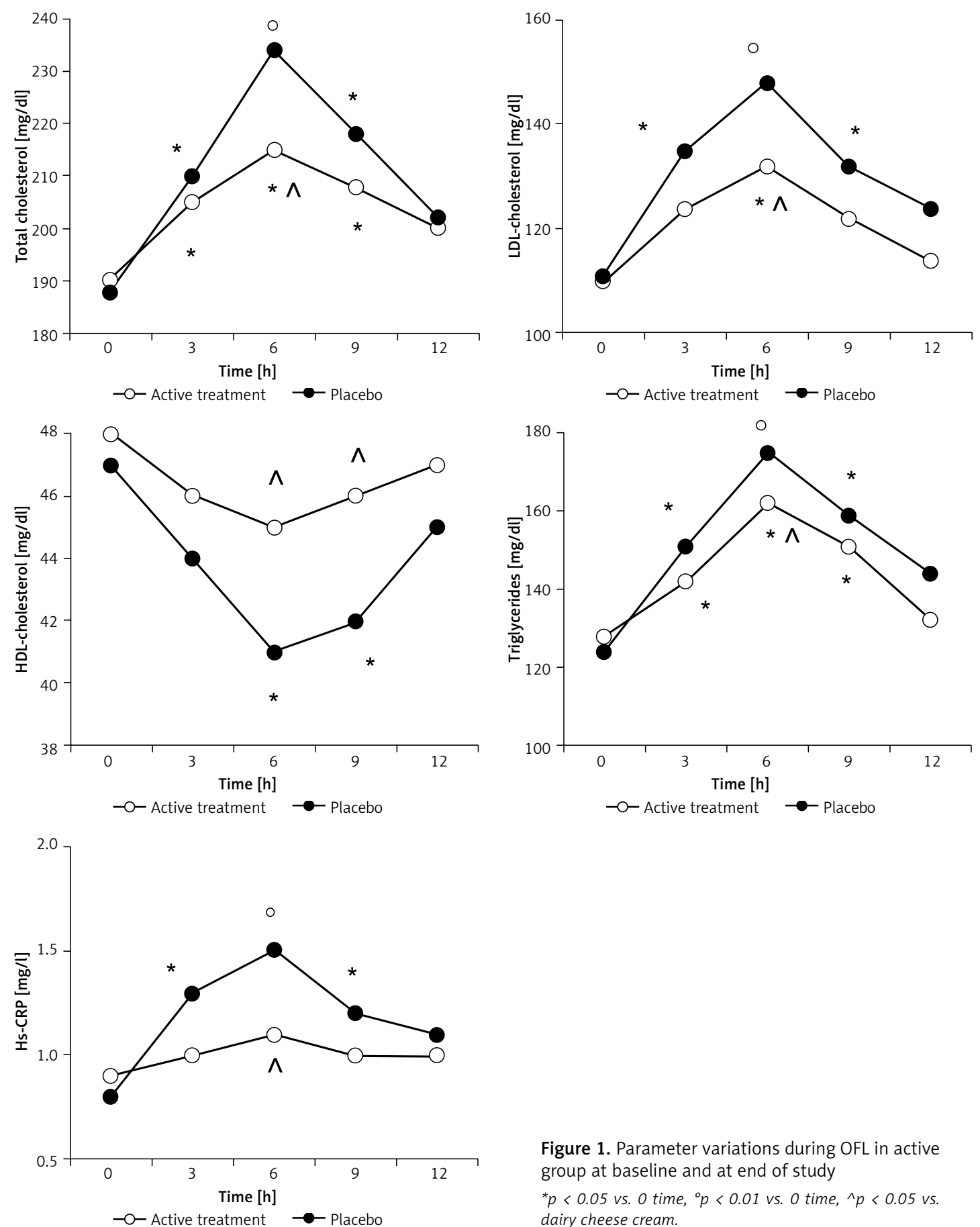

and the short observational period are further limitations.

In conclusion, a non-dairy cheese cream, containing $75 \%$ fermented soybean extract, caused a minor increase of lipid profile and of hs-CRP during OFL compared to a dairy cheese cream in healthy subjects.

\section{Acknowledgments}

This research was supported by Valsoia, which provided medications without charge. Valsoia had

Figure 1. Parameter variations during OFL in active group at baseline and at end of study

${ }^{*} p<0.05$ vs. 0 time, ${ }^{\circ} p<0.01$ vs. 0 time, ${ }^{\wedge} p<0.05$ vs. dairy cheese cream.

no role in the design, analysis or writing of this article.

\section{Conflict of interest}

The authors declare no conflict of interest.

\section{References}

1. McBride PE. Triglycerides and risk for coronary heart disease. JAMA 2007; 298: 336-8.

2. Nordestgaard BG, Benn M, Schnohr P, Tybjaerg-Hansen A. Nonfasting triglycerides and risk of myocardial 
infarction, ischemic heart disease, and death in men and women. JAMA 2007; 298: 299-308.

3. Groot PH, van Stiphout WA, Krauss XH, et al. Postprandial lipoprotein metabolism in normolipidemic men with and without coronary artery disease. Arterioscler Thromb 1991; 11: 653-62.

4. Maggi FM, Raselli S, Grigore L, Redaelli L, Fantappiè S, Catapano AL. Lipoprotein remnants and endothelial dysfunction in the postprandial phase. J Clin Endocrinol Metab 2004; 89: 2946-50.

5. Karpe F, Steiner G, Uffelman K, Olivecrona T, Hamsten A. Postprandial lipoproteins and progression of coronary atherosclerosis. Atherosclerosis 1994; 106: 83-97.

6. Parks EJ. Recent findings in the study of postprandial lipemia. Curr Atheroscler Rep 2001; 3: 462-470.

7. Van Oostrom AJ, Alipour A, Plokker TW, Sniderman AD, Cabezas MC. The metabolic syndrome in relation to complement component 3 and postprandial lipemia in patients from an outpatient lipid clinic and healthy volunteers. Atherosclerosis 2007; 190: 167-73.

8. Peake PW, Kriketos AD, Campbell LV, Charlesworth JA. Response of the alternative complement pathway to an oral fat load in first-degree relatives of subjects with type II diabetes. Int J Obes 2005; 29: 429-35.

9. Derosa G, Ferrari I, D’Angelo A, et al. Oral fat load effects on inflammation and endothelial stress markers in healthy subjects. Heart Vessels 2009; 24: 204-10.

10. Derosa G, Ferrari I, D’Angelo A, et al. Effects of a standardized oral fat load on vascular remodelling markers in healthy subjects. Microvasc Res 2010; 80: 110-5.

11. Bhagat U, Das UN. Potential role of dietary lipids in the prophylaxis of some clinical conditions. Arch Med Sci 2015; 11: 807-18.

12. Khan N, Akhtar MS, Khan BA, Braga Vde A, Reich A. Antiobesity, hypolipidemic, antioxidant and hepatoprotective effects of Achyranthes aspera seed saponins in high cholesterol fed albino rats. Arch Med Sci 2015; 11: 1261-71.

13. Ursoniu S, Sahebkar A, Serban MC, Banach M. Lipid profile and glucose changes after supplementation with astaxanthin: a systematic review and meta-analysis of randomized controlled trials. Arch Med Sci 2015; 11 : 253-66

14. Sahebkar A, Serban MC, Gluba-Brzózka A, et al. Lipidmodifying effects of nutraceuticals: an evidencebased approach. Nutrition 2016; 32: 1179-92.

15. Patti AM, Toth PP, Giglio RV, et al. Nutraceuticals as an important part of combination therapy in dyslipidaemia. Curr Pharm Des 2017; 23: 2496-503.

16. Manzoni C, Lovati MR, Agostinelli P, Sirtori CR. Studies on the mechanism of the cholesterol lowering activity of soy proteins. Pharmacol Res 1990; 22: 300.

17. Scientific Opinion of the Panel on Dietetic Products, Nutrition and Allergies. Scientific Opinion on the substantiation of a health claim related to soy protein and reduction of blood cholesterol concentrations pursuant to Article 14 of the Regulation (EC) No 1924/20061. EFSA 2010; 8: 1688-702

18. Clarkson TB. Soy, soy phytoestrogens and cardiovascular disease. J Nutr 2002; 132: 566S-9S.

19. Forsythe WA, Green MS, Anderson JJ. Dietary protein effects on cholesterol and lipoprotein concentrations: a review. J Am Coll Nutr 1986; 5: 533-49.

20. Nagata C, Takatsuka N, Kurisu Y, Shimizu H. Decreased serum total cholesterol concentration is associated with high intake of soy products in Japanese men and women. J Nutr 1998; 128: 209-13.

21. Ho SC, Woo JL, Leung SS, Sham AL, Lam TH, Janus ED. Intake of soy products is associated with better plas- ma lipid profiles in the Hong Kong Chinese population. J Nutr 2000; 130: 2590-3.

22. Proposed International Guidelines for Biomedical Research Involving Human Subjects. The Council for International Organisation of Medical Sciences. Geneva, 1982.

23. Guidelines Subcommittee 1999 World Health Organization-International Society of Hypertension Guidelines for the Management of Hypertension. J Hypertens 1999; 17: 151-83

24. NCEP. Third Report of the National Cholesterol Education Program (NCEP) Expert Panel on Detection, Evaluation, and Treatment of High Blood Cholesterol in Adults (Adult Treatment Panel III) final report. Circulation 2002; 106: 3143-421.

25. Lichtenstein AH, Appel LJ, Brands M, et al. Summary of American Heart Association Diet and Lifestyle Recommendations Revision 2006. Arterioscler Thromb Vasc Biol 2006; 26: 2186-91.

26. Derosa G, Maffioli P, Salvadeo SA, et al. Fenofibrate, simvastatin and their combination in the management of dyslipidaemia in type 2 diabetic patients. Curr Med Res Opin 2009; 25: 1973-83.

27. Winer BJ. Statistical Principles in Experimental Design. $2^{\text {nd }}$ ed., McGraw-Hill, New York (USA) 1971.

28. Shige H, Ishikawa T, Higashi K, et al. Effects of soy protein isolate (SPI) and casein on the postprandial lipemia in normolipidemic men. J Nutr Sci Vitaminol (Tokyo) 1998; 44: 113-27.

29. Vahouny GV, Chalcarz W, Satchitanandam S, Adamson I, Klurfeld DM, Krichevski D. Effect of soy protein and casein intake on intestinal absorption and lymphatic transport of cholesterol and oleic acid. Am J Clin Nutr 1984; 40: 1156-64.

30. Sirtori CR, Galli G, Lovati MR, Carrara P, Bosisio E, Galli-Kienle $M$. Effects of dietary proteins on the regulation of liver lipoprotein receptors in rat. J Nutr 1984; 114: 1493-500.

31. Chon JS, Nestel PJ. Hepatic lipoprotein receptor activity in rat fed casein and soy protein. Atherosclerosis 1985; 56: 247-50.

32. Lovati MR, Manzoni C, Canavesi A, et al. Soybean protein diet increased low density lipoprotein receptor activity in mononuclear cells from hypercholesterolemic patients. J Clin Invest 1987; 80: 1498-502.

33. Gaddi A, Ciarocchi A, Matteucci A, et al. Dietary treatment for familial hypercholesterolemia-differential effects of dietary soy protein according to the apolipoprotein E phenotype. Am J Clin Nutr 1991; 53: 1191-6.

34 . Forsythe WA. Comparison of dietary casein or soy protein effects on plasma lipids and hormone concentration in the gerbil. J Nutr 1986; 116: 1165-71.

35. Vessby B, Karlstrom B, Lithell H, Gustafsson TB, Werner I. The effects on lipid and carbohydrate metabolism of replacing some animal protein by soy protein in a lipid-lowering diet for hypercholesterolemic patients. Human Nutr Appl Nutr 1982; 36: 179-89.

36. Alipour A, Elte JW, van Zaanen HC, Rietveld AP, Cabezas MC. Postprandial inflammation and endothelial dysfunction. Biochem Soc Trans 2007; 35: 466-9. 